\title{
Dendritic Cell-Derived Tumor Necrosis Factor $\alpha$ Modifies Airway Epithelial Cell Responses
}

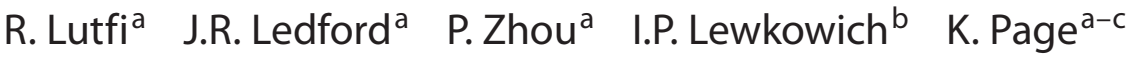

Divisions of a Critical Care Medicine and b Immunobiology, Cincinnati Children's Hospital Medical Center and Cincinnati Children's Research Foundation, and 'Department of Pediatrics, University of Cincinnati,

Cincinnati, Ohio, USA

\section{Key Words}

Airway · Chemokines $\cdot$ Cytokines • Dendritic cells ·

Epithelium $\cdot$ Immune responses $\cdot$ Inflammation $\cdot$ Tumor

necrosis factor $\alpha$

\begin{abstract}
Mucosal dendritic cells (DC) are intimately associated with the airway epithelium and thus are ideally situated to be first responders to pathogens. We hypothesize that DC drive innate immune responses through early release of tumor necrosis factor (TNF) $\alpha$, which drives airway epithelial cell responses. In a mouse model, TNF $\alpha$ release was significantly increased following a single exposure to German cockroach (GC) frass, an event independent of neutrophil recruitment into the airways. While lung epithelial cells and alveolar macrophages failed to release TNF $\alpha$ following GC frass exposure, bone marrow-derived DC (BMDC) produced substantial amounts of TNF $\alpha$ suggesting their importance as early responding cells. This was confirmed by flow cytometry of pulmonary myeloid DC. Addition of GC frass-pulsed BMDC or conditioned media from GC frass-pulsed BMDC to primary mouse tracheal epithelial cells (MTEC) or MLE-15 cells induced chemokine (C-C) motif ligand (CCL) 20 and granulocyte macrophage (GM) colony-stimulating factor (CSF), both
\end{abstract}

of which are important for DC recruitment, survival and differentiation. Importantly, DC do not produce CCL20 or GMCSF following allergen exposure. Blocking TNF $\alpha$ receptor 1 (TNFR1) completely abolished chemokine production, suggesting that BMDC-derived TNF $\alpha$ induced airway epithelial cell activation and enhancement of the innate immune response. Lastly, blocking TNFR1 in vivo resulted in significantly decreased CCL20 and GM-CSF production in the lungs of mice. Together, our data strongly suggest that DC-derived TNF $\alpha$ plays a crucial role in the initiation of innate immune responses through the modification of airway epithelial cell responses.

Copyright $\odot 2012$ S. Karger AG, Basel

\section{Introduction}

Asthma is a common chronic disorder of the airways which is the result of an aberrant response to ubiquitous, otherwise innocuous environmental proteins or allergens at the airway mucosa. While the main immune function of the mucosal epithelium was initially thought to be a physical barrier, it is now accepted that it also plays an important role in modulating innate immune responses. Many investigators have suggested that asth-

\section{KARGER}

Fax +41613061234

E-Mail karger@karger.ch

www.karger.com (c) 2012 S. Karger AG, Basel

1662-811X/12/0046-0542\$38.00/0

Accessible online at:

www.karger.com/jin
Dr. Kristen Page

Division of Critical Care Medicine, Cincinnati Children's Hospital Medical Center 3333 Burnet Avenue, ML 7006

Cincinnati, OH 45229 (USA)

Tel. +1 513636 3079, E-Mail kristen.page@cchmc.org 
matic individuals may have a dysfunctional airway epithelium which is characterized by abnormal cytokine responses and impaired barrier function. Evidence for defective epithelial repair was suggested in a number of studies. Epidermal growth factor (EGF) receptor expression was significantly increased in mild and severe asthmatic epithelium and was positively correlated with subepithelial reticular membrane thickening [1]. Airway epithelial cells from individuals with asthma display abnormal EGF release, plasminogen activator inhibitor-1 expression and extracellular matrix production, including cytokeratin 19 and fibronectin, all of which have been associated with defective repair in asthma [2-4]. Nasal epithelial cells and primary bronchial epithelial cells from asthmatic individuals were shown to release significantly greater amounts of interleukin (IL)-8 and granulocyte macrophage (GM) colony-stimulating factor (CSF) than from non-asthmatic individuals $[5,6]$. However, while a subsequent study showed no significant difference in IL- 8 and GM-CSF levels in normal and asthmatic bronchial epithelial cells from epithelial brushings, asthmatic epithelial cells showed an increased response to tumor necrosis factor (TNF) $\alpha$ regarding the production of transforming growth factor (TGF) $\alpha$ [7]. Thus, the airway epithelium may be regulated by the conditions in the airway microenvironment, but there may also be fundamental changes in the airway epithelium in patients with asthma.

$\mathrm{TNF} \alpha$ is a proinflammatory cytokine that has been implicated in many aspects of airway pathology in asthma. TNF $\alpha$ was shown to be required for airway hyperresponsiveness, eosinophilia, increased Th2 and Th17 cytokines and pulmonary inflammation using a murine model of ovalbumin-induced pulmonary allergic inflammation in the absence of adjuvant [8]. Increased levels of TNF $\alpha$ have been found in asthmatic airways $[9,10]$; recently, repeated low-dose allergen exposure was shown to upregulate $\mathrm{TNF} \alpha$ production in the airways of human subjects with mild asthma [11]. Importantly, TNF $\alpha$ can directly affect airway epithelial cell production of a number of cytokines and chemokines, including chemokine C-C motif ligand 20 (CCL20) [12], a unique ligand for the chemokine CCR6 which is expressed on circulating immature dendritic cells (DC) [13], and GM-CSF [14], which is important for DC recruitment, survival and differentiation. This suggests that TNF $\alpha$ may be important in the initiation of the allergic airway response as well as in the maintenance of airway inflammation.

Recently, we showed a significant release of $\mathrm{TNF} \alpha$ within $3 \mathrm{~h}$ following a single exposure to the allergen
German cockroach (GC) frass that was maintained at $6 \mathrm{~h}$ and returned to baseline levels $24 \mathrm{~h}$ after challenge [15]. While we did not identify the source of TNF $\alpha$, based on the kinetics following a single exposure to allergen in naïve mice, it is possible that this early release of TNF $\alpha$ could play a role in the activation of airway epithelial cells, possibly to direct or augment their response to allergen exposure. The main cellular source of TNF $\alpha$ in allergic airway inflammation is thought to be from preformed stores in mast cells and released during IgE-mediated reactions [16]; however mast cells would not be present at the initial encounter with allergen. Recently, myeloid DC (mDC) were shown to produce TNF $\alpha$ following allergen challenge [17] and these cells could be a likely source of the early increase in TNF $\alpha$. Mucosal DC are intimately associated with the mucosal epithelium and extend dendrites through the tight junctions between epithelial cells to survey the airways [18]. Jahnsen et al. [19] confirmed the presence of intraepithelial DC populations and found these constituted approximately $20 \%$ of the total airway mucosal DC. Thus DC are not only important as antigen-presenting cells which bridge innate and adaptive immune responses but, due to their location, may also serve as a trigger in innate immune responses. Therefore, based on the finding that $\mathrm{mDC}$ were shown to produce TNF $\alpha$ following allergen challenge [17], we hypothesized that the mucosal DC is a prime initiator of very early innate immune responses by secreting significant amounts of $\mathrm{TNF} \alpha$, which in turn acts directly on airway epithelium to induce cytokine and chemokine production. The end effect is the ability of the DC to alter the airway microenvironment leading to the modification of epithelial cell responses.

\section{Materials and Methods}

\section{Cockroach Frass}

The fecal remnants (frass) from one cage of GC were transferred to a sterile container and stored at $4^{\circ} \mathrm{C}$. GC frass was resuspended in PBS (divalent free; Gibco/Invitrogen, Carlsbad, Calif., USA) made with endotoxin-free double-distilled water $\left(2 \mathrm{~h}\right.$ at $4{ }^{\circ} \mathrm{C}$ while rocking). Extracts were centrifuged to remove debris $\left(10,000 \mathrm{~g}\right.$ for $5 \mathrm{~min}$ at $\left.4^{\circ} \mathrm{C}\right)$, supernatants were harvested, and total protein was measured using the Bio-Rad Protein Assay Dye (Bio-Rad, Hercules, Calif., USA).

\section{Animals and Exposure Protocol}

Six-week-old female BALB/c mice were obtained from the Jackson Laboratory (Bar Harbor, Me., USA). Mice were anesthetized with ketamine $(45 \mathrm{mg} / \mathrm{kg}) /$ xylazine $(8 \mathrm{mg} / \mathrm{kg})$ prior to $\mathrm{PBS}$ or GC frass $(40 \mu \mathrm{g} / 40 \mu \mathrm{l})$ exposure by a single inhalation as described previously [20-22]. Mice were given a lethal dose of so- 
dium pentobarbital 1-3 h later. In one experiment, mice were injected intraperitoneally with the anti-granulocyte monoclonal antibody (mAb) Rb5-8C5 (also referred to as Ly6g; BD Pharmingen, San Diego, Calif., USA) at a concentration of $100 \mu \mathrm{g} / \mathrm{mouse}$ [23] $24 \mathrm{~h}$ before inhalation. In another experiment, hamster IgG isotype control antibody or mouse TNF receptor (TNFR) 1 antibody (R\&D Systems, Minneapolis, Minn., USA) was instilled once into the airways ( $25 \mu \mathrm{g} / \mathrm{mouse})$. Twenty-four hours later, mice were given a single treatment with PBS or GC frass and sacrificed $3 \mathrm{~h}$ later. Animal care was provided in accordance with $\mathrm{NIH}$ guidelines. These studies were approved by the Cincinnati Children's Hospital Medical Center Institutional Animal Care and Use Committee.

Assessment of Airway Cytokine and Chemokine Levels

Lungs were lavaged with $1 \mathrm{ml}$ of Hanks balanced salt solution without calcium or magnesium. The lavage fluid was centrifuged ( $300 \mathrm{~g}$ for $10 \mathrm{~min}$ ), and the supernatant was removed and immediately stored at $-80^{\circ} \mathrm{C}$. Bronchoalveolar lavage (BAL) fluid was analyzed for $\mathrm{TNF} \alpha$, CCL20 and GM-CSF using ELISA kits purchased from R\&D Systems.

\section{Isolation and Development of Mature, GC Frass-Pulsed Bone} Marrow-Derived $m D C$

Mice were given a lethal dose of sodium pentobarbital prior to tibias and femur removal. Bone marrow cells $\left(1.5 \times 10^{7}\right.$ cells $\left./ \mathrm{ml}\right)$ were cultured on complete RPMI supplemented with GM-CSF (10 ng/ml; Peprotech, Rocky Hills, N.J., USA). Fresh media was added along with GM-CSF $(10 \mathrm{ng} / \mathrm{ml})$ on day 3 . On day 6 , cells were washed, counted and plated $\left(1 \times 10^{6}\right.$ cells $\left./ \mathrm{ml}\right)$ for experimentation. Cells were then treated with endotoxin-free PBS or GC frass $(1 \mu \mathrm{g} / \mathrm{ml})$ for $18 \mathrm{~h}$. Cytokine levels were assessed following clarification of the cell culture media $\left(13,000 \mathrm{~g}\right.$ for $5 \mathrm{~min}$ at $\left.4^{\circ} \mathrm{C}\right)$. Bone marrow-derived DC (BMDC) were $>95 \% \mathrm{mDC}$ as characterized by CD11c+, CD11b+, Gr1- and PDCA- (data not shown).

\section{Quantitative Real-Time PCR}

BMDC $\left(5 \times 10^{6}\right)$ were treated with or without GC frass $(1 \mu \mathrm{g} /$ $\mathrm{ml}$ ) for $4 \mathrm{~h}$. RNA was extracted using a standard TRIzol method of phenol extraction. Total RNA was converted to cDNA by reverse transcription using the Superscript first-strand synthesis system kit (Invitrogen). The TNF $\alpha$ primers used were $5^{\prime}$ AGCCCCCAGTCTGTATCCTT-3' and 5'-CTCCCTTTGCAGAACTCAGG- $3^{\prime}$, and the $\beta$-actin primers used were $5^{\prime}$ TGTTACCAACTGGGACGACA-3' and $5^{\prime}$-GGGGTGTTGAAGGTCTCAAA-3'. Amplification was performed by PCR using SYBR Green on the iCycler (Bio-Rad Laboratories) as follows: 1 cycle at $95^{\circ} \mathrm{C}$ for $3 \mathrm{~min}$, followed by 40 cycles at $95^{\circ} \mathrm{C}$ for $5 \mathrm{~s}$, $57^{\circ} \mathrm{C}$ for $5 \mathrm{~s}$ and $72^{\circ} \mathrm{C}$ for $10 \mathrm{~s} ; 95^{\circ} \mathrm{C}$ for $1 \mathrm{~min} ; 55^{\circ} \mathrm{C}$ for $1 \mathrm{~min}$, and then a hold at $25^{\circ} \mathrm{C}$. The target gene was normalized to the reference gene using the method of Pfaffl [24].

\section{Alveolar Macrophages}

The lungs of naïve BALB/c mice were lavaged three times with sterile PBS. The lavage fluid was centrifuged ( $300 \mathrm{~g}$ for $10 \mathrm{~min}$ ), and cells were counted and plated at $5 \times 10^{5}$ cells/well in 12-well plates. Cells were treated with or without GC frass $(1 \mu \mathrm{g} / \mathrm{ml})$ and supernatants were harvested $18 \mathrm{~h}$ later for analysis of TNF $\alpha$ by ELISA (R\&D Systems, Minneapolis, Minn., USA).
Mouse Tracheal Epithelial Cells

Tracheas from 4-week-old mice were removed from the thyroid cartilage to the level of the bifurcation and incubated in Pronase ( $1 \mathrm{mg} / \mathrm{ml}$; Roche Applied Science, Indianapolis, Ind., USA) and incubated (18 h at $4^{\circ} \mathrm{C}$ while rocking). The next day, $10 \% \mathrm{FBS}$ and $1 \mathrm{mg} / \mathrm{ml}$ DNase (Sigma-Aldrich, St. Louis, Mo., USA) was added to the tube and inverted multiple times. The trachea was discarded; cells were washed and plated onto a cell culture plate with Primaria surface treatment (BD Biosciences, Bedford, Mass., USA) for $4 \mathrm{~h}$ to remove fibroblasts. Non-attached cells were washed, counted and plated in DMEM/F12 (50/50) containing Lglutamine $(2 \mathrm{mM})$, penicillin $(100 \mathrm{U} / \mathrm{ml}) /$ streptomycin $(100 \mu \mathrm{g} /$ $\mathrm{ml}), \mathrm{NaHCO}_{3}(3.6 \mathrm{mM})$, FBS $(5 \%)$, cholera toxin $(0.1 \mu \mathrm{g} / \mathrm{ml})$, mouse EGF $(0.5 \mathrm{ng} / \mathrm{ml})$, amphotericin B $(0.25 \mu \mathrm{g} / \mathrm{ml})$, bovine pituitary extract $(50 \mu \mathrm{g} / \mathrm{ml})$, insulin-transferrin-selenium medium supplement (Sigma, St. Louis, Mo., USA) and retinoic acid (0.1 ng/ $\mathrm{ml}$ ). Mouse tracheal endothelial cells (MTEC) were grown on collagen-coated culture plates until confluent. Cells were treated with PBS or GC frass $(1 \mu \mathrm{g} / \mathrm{ml})$ for $18 \mathrm{~h}$. In some cases, MTEC medium was removed and replaced with cell-free conditioned media (CM) from PBS- or GC frass-treated BMDC for $18 \mathrm{~h}$. Supernatants were harvested, clarified and analyzed for CCL20 and GM-CSF by ELISA.

\section{Mouse Alveolar Type II Cells (MLE-15)}

MLE-15 cells [25] (a gift from Dr. Jeffrey Whitsett, Cincinnati Children's Hospital, Cincinnati, Ohio, USA) were cultured in HITES medium (RPMI 1640 medium; Invitrogen) supplemented with $10 \mathrm{nM}$ hydrocortisone, $5 \mu \mathrm{g} / \mathrm{ml}$ insulin, $5 \mu \mathrm{g} / \mathrm{ml}$ human transferrin, $10 \mathrm{nM} \beta$-estradiol, $5 \mu \mathrm{g} / \mathrm{ml}$ selenium, $2 \mathrm{~mm}$ L-glutamine, $10 \mathrm{mM}$ HEPES, $100 \mathrm{U} / \mathrm{ml}$ penicillin, $100 \mu \mathrm{g} / \mathrm{ml}$ streptomycin and 2\% FBS. Upon confluence, cells were treated with GC frass $(1 \mu \mathrm{g} / \mathrm{ml}), \mathrm{TNF} \alpha(10 \mathrm{ng} / \mathrm{ml})$ or both together for $18 \mathrm{~h}$. In some cases, media were removed and cell-free CM from PBS- or GC frass-treated BMDC was added. In some experiments, a TNFR1-blocking antibody ( $1 \mu \mathrm{g} / \mathrm{ml}$; R\&D Systems) or a control antibody ( $1 \mu \mathrm{g} / \mathrm{ml}$; Santa Cruz, Santa Cruz, Calif., USA) was added immediately following the addition of DC-CM onto the MLE15 cells. To directly add BMDC to MLE-15 cells, BMDC were treated with PBS or GC frass $(1 \mu \mathrm{g} / \mathrm{ml})$ for $6 \mathrm{~h}$, washed with PBS twice and counted, and $1 \times 10^{6}$ cells were co-cultured with MLE15 cells and incubated for $18 \mathrm{~h}$. In all experiments, $18 \mathrm{~h}$ later, the supernatant was harvested, clarified by centrifugation $(10,000 \mathrm{~g}$ $\times 10 \mathrm{~min} \times 4^{\circ} \mathrm{C}$ ) and analyzed for CCL20 and GM-CSF by ELISA.

\section{Flow Cytometry}

Following inhalation of PBS or GC frass $(40 \mu \mathrm{g} / 40 \mu \mathrm{l})$, whole lungs were isolated from mice, minced and placed in RPMI 1640 containing Liberase CI $(0.5 \mathrm{mg} / \mathrm{ml}$; Roche Diagnostics, Indianapolis, Ind., USA) and DNase I ( $0.5 \mathrm{mg} / \mathrm{ml}$; Sigma $)$ at $37^{\circ} \mathrm{C}$ for 45 $\mathrm{min}$. The tissue was forced through a $70-\mu \mathrm{m}$ cell strainer, and red blood cells were lysed with ACK lysis buffer (Invitrogen). Cells were washed with RPMI containing $10 \%$ FBS, counted and plated at 350,000 cells/well in a 96-well plate. Cells were immediately fixed and permeabilized (BD Cytofix/Cytoperm Plus with BD GolgiPlug). Cells were blocked with Fc block (mAb 2.4G2) for 30 min at $4^{\circ} \mathrm{C}$. Staining was performed in Fc block with the permeabilization buffers at $4^{\circ} \mathrm{C}$ following incubation. $\mathrm{mDC}(\mathrm{CD} 11 \mathrm{c}+$, CD11b+, Gr1-, CD317-) were quantified using anti-CD11c-APC 
Fig. 1. A single exposure to GC frass induced early cytokine release into mouse airways. Naïve mice were administered a single intratracheal inhalation of PBS (40 $\mu \mathrm{l})$ or GC frass $(40 \mu \mathrm{g} / 40 \mu \mathrm{l})$ and 1 or $3 \mathrm{~h}$ later, BAL fluid was isolated and clarified, and neutrophils were quantified following differential staining. ELISA was performed on the BAL fluid. In all cases, means \pm SEM are reported for each chemokine (in ng/ml; $\mathrm{n}=6-8 \mathrm{mice} /$ group). ${ }^{*} \mathrm{p}<0.001$ (ANOVA). TNF $\alpha$ levels at 1 (a) and $3 \mathrm{~h}$ (c). Neutrophil counts at 1 (b) and $3 \mathrm{~h}(\mathbf{d})$.

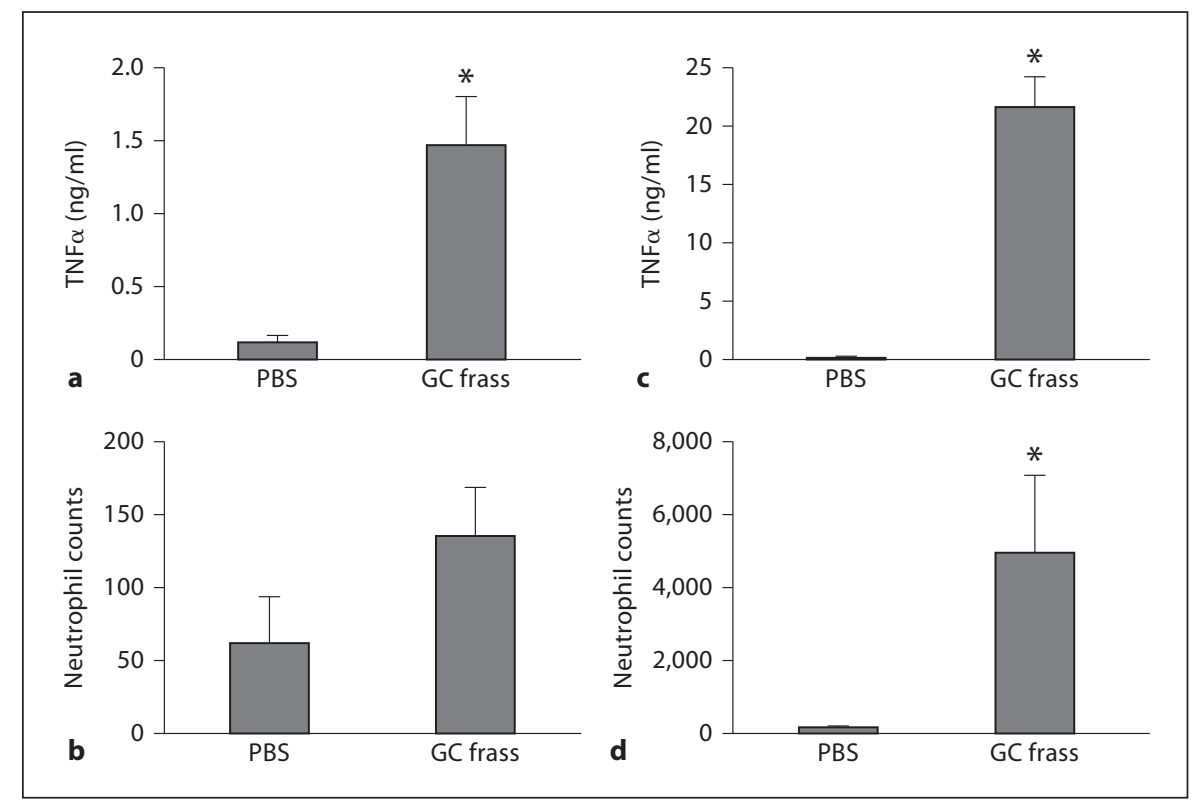

(HL3), anti-CD11b-PE-Cy7 (M1/70) and anti GR-1-APC-Cy7 (RB6-8C5). TNF $\alpha$ expression was examined using PE-conjugated $\mathrm{mAb}$ to $\mathrm{TNF} \alpha$. All antibodies and reagents were purchased from eBioscience (San Diego, Calif., USA). Data were acquired with an LSRII flow cytometer (BD Biosciences, San Jose, Calif., USA). Spectral overlap was compensated using the FACSDiVa software (BD Biosciences) and analyzed using FlowJo software (Treestar, Ashland, Oreg., USA).

\section{Statistical Analysis}

Statistical significance was assessed by Student's t test or by one-way analysis of variance (ANOVA), as appropriate (SigmaPlot version 11; Systat Software, Chicago, Ill., USA). Differences identified by ANOVA were pinpointed by Student-NewmanKeuls' multiple range test.

\section{Results}

\section{A Single Exposure to GC Frass Induced an Early Innate Immune Response}

Naïve BALB/c mice were exposed to a single intratracheal inhalation of PBS or GC frass and sacrificed 1 and $3 \mathrm{~h}$ later. TNF $\alpha$ levels were measured in the BAL fluid of these mice. Within $1 \mathrm{~h}$ of allergen exposure, TNF $\alpha$ significantly increased (fig. 1a). At this time point, there was a trend towards increased neutrophil infiltration into the lungs; however, these levels did not reach statistical significance (fig. 1b). By $3 \mathrm{~h}$ after allergen inhalation, TNF $\alpha$ levels were $>30$-fold higher than in mice that inhaled PBS (fig. 1c). There was also a significant increase in the number of newly recruited neutrophils in the lungs at this time point (fig. 1d). These data highlight the immediate response to GC frass which is mounted in vivo following exposure to a common allergen.

\section{Neutrophils Are Not the Primary Source of TNF $\alpha$}

We wanted to determine if the immediate cytokine release was dependent on newly recruited neutrophils in the airways. Therefore, mice were pretreated with R6B-8C5 (an antibody that depletes circulating neutrophils [23]) $24 \mathrm{~h}$ before a single allergen exposure. BAL fluid was isolated $3 \mathrm{~h}$ after challenge and analyzed for TNF $\alpha$ expression and neutrophil recruitment. While pretreatment with R6B-8C5 antibody had no effect on TNF $\alpha$ levels in the BAL fluid of mice (fig. 2a), it totally abolished neutrophil recruitment into the BAL fluid (fig. 2b). These data indicate that the significant release of inflammatory cytokines at this very early time point following allergen exposure is not due to the release of neutrophils in the airways.

\section{DC and Macrophages, but Not Epithelial Cells or}

Alveolar Type II Cells, Are Sources of Allergen-Derived TNF $\alpha$

To determine the source of allergen-derived $\operatorname{TNF} \alpha$, we isolated MTEC and cultured them in the presence of GC frass $(1 \mu \mathrm{g} / \mathrm{ml})$ for $18 \mathrm{~h}$. MTEC failed to release TNF $\alpha$ following stimulation with GC frass (table 1). We also tested the release of TNF $\alpha$ from MLE-15 cells, an immortalized cell line derived from alveolar type II epithelial 


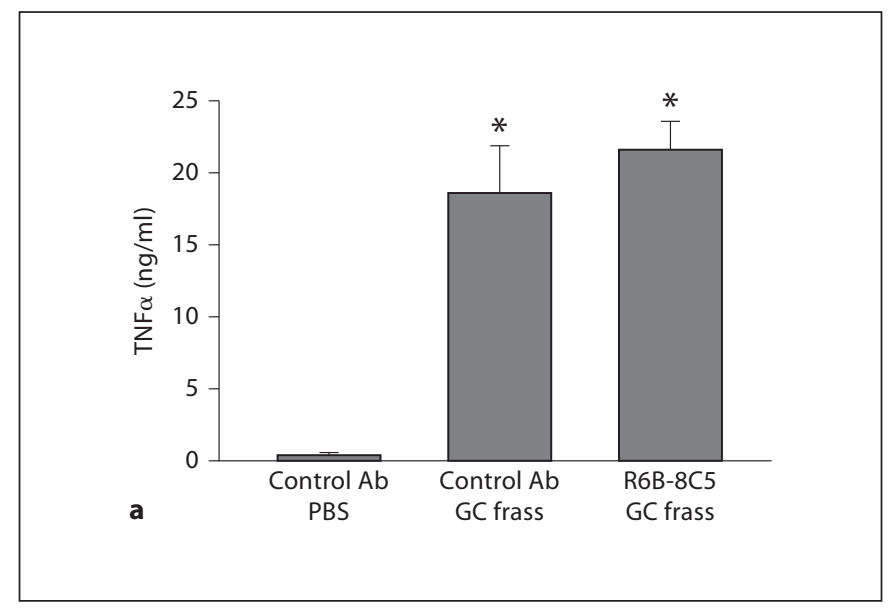

Fig. 2. Neutrophil depletion has no effect on cytokine release into the airways of mice. Naïve mice were given a single injection of control Ab or RB5-8C5 (100 $\mu \mathrm{g} / \mathrm{mouse}) 24 \mathrm{~h}$ prior to a single exposure to PBS $(40 \mu \mathrm{l})$ or GC frass $(40 \mu \mathrm{g} / 40 \mu \mathrm{l}) ; 3 \mathrm{~h}$ later, BAL fluid was isolated and clarified, and neutrophils were quantified

Table 1. TNF $\alpha$ production following GC frass treatment

\begin{tabular}{lcc}
\hline & \multicolumn{2}{l}{ TNF $\alpha, p g / m l(m e a n s \pm$ SEM) } \\
\cline { 2 - 3 } & PBS & GC frass \\
\hline MTEC & $52 \pm 9$ & $88 \pm 27$ \\
MLE-15 & $6 \pm 2$ & $17 \pm 5$ \\
AM & ND & $183 \pm 74$ \\
BMDC & $54 \pm 12$ & $5,342 \pm 875^{*}$ \\
\hline
\end{tabular}

Airway epithelial cells (MTEC and MLE-15), alveolar macrophages (AM) and BMDC release of TNF $\alpha$ following treatment with PBS or GC frass $(1 \mu \mathrm{g} / \mathrm{ml})$ for $18 \mathrm{~h}$. Data represent $4-8$ separate experiments per cell type. ND = none detected. Student's $t$ test $\left({ }^{*} \mathrm{p}<0.001\right)$.

cells, and found no increase in TNF $\alpha$ release following GC frass treatment (table 1). Next we isolated alveolar macrophages from naïve mice and treated them for $18 \mathrm{~h}$ ex vivo with GC frass $(1 \mu \mathrm{g} / \mathrm{ml})$. While TNF $\alpha$ production was induced, the levels were significantly lower than what we detected in the BAL fluid following allergen challenge (table 1). Since DC are intimately associated with airway epithelium and are continuously monitoring the airway environment, we queried the role of DC in TNF $\alpha$ production. We generated BMDC by culturing bone marrow cells in the presence of GM-CSF for 6 days which results in $95 \%$ of the cells becoming $\mathrm{mDC}$, as characterized by flow cytometry (CD11c+, CD11b+, Gr1-, CD317-; data

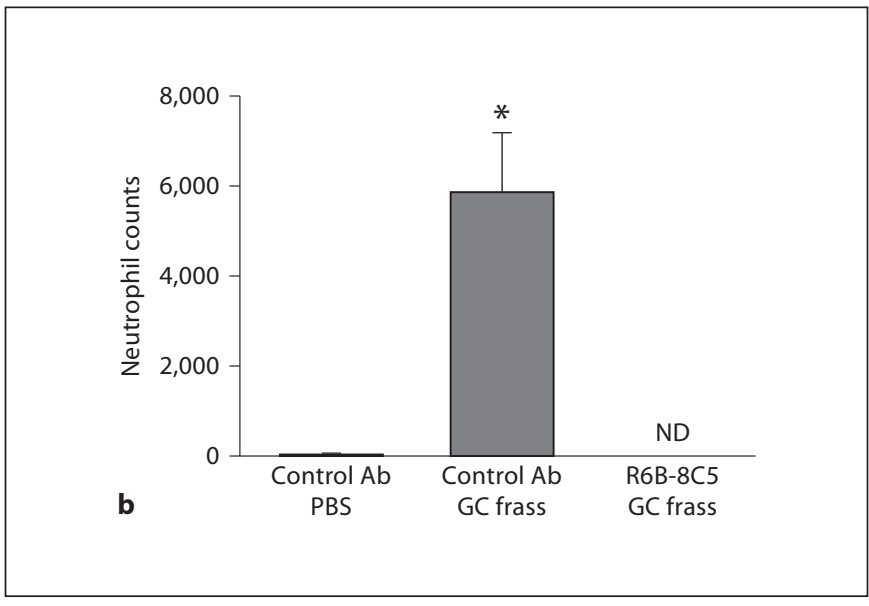

following differential staining. ELISA was performed on the BAL fluid. In all cases, means \pm SEM are reported for each chemokine (in $\mathrm{ng} / \mathrm{ml} ; \mathrm{n}=6$ mice/group). ${ }^{*} \mathrm{p}<0.001$ (ANOVA). a TNF $\alpha$ levels. b Neutrophil count. ND $=$ None detected.

not shown). When treated with GC frass for $18 \mathrm{~h}$, $\mathrm{mDC}$ released a significant amount of TNF $\alpha$ (table 1). TNF $\alpha$ released from DC occurred in a time-dependent manner, with a significant increase in TNF $\alpha$ within $1 \mathrm{~h}$ of exposure to GC frass (fig. 3a). GC frass induced TNF $\alpha$ mRNA levels $4 \mathrm{~h}$ following stimulation with GC frass (fig. $3 \mathrm{~b}$ ). Thus, our data confirm a role for DC in mediating TNF $\alpha$ release following exposure to an allergen and suggest the potential importance of these cells in the initiation of an early innate immune response.

\section{Pulmonary mDC Synthesize TNF $\alpha$ following GC}

Frass Inhalation

To confirm that a single exposure to allergen could induce intracellular $\mathrm{TNF} \alpha$ expression in pulmonary $\mathrm{mDC}$, we performed a single intratracheal inhalation of $\mathrm{GC}$ frass and isolated the lungs $3 \mathrm{~h}$ later. The lungs were dissociated, immediately fixed and permeabilized, and then stained for flow cytometry. mDC (CD11c+, CD11b+, Gr1-) were analyzed for intracellular TNF $\alpha$ levels. Following GC frass exposure, the number of TNF $\alpha$-positive $\mathrm{mDC}$ in the lung increased, while the numbers of TNF $\alpha$ positive alveolar macrophages and neutrophils did not increase (table 2). Pulmonary $\mathrm{mDC}$ expressed a higher level of intracellular $\mathrm{TNF} \alpha$ staining (fig. 4a), which corresponded to an increased percentage of $\mathrm{TNF} \alpha$-positive $\mathrm{mDC}$ (fig. 4b). The mean fluorescence intensity was not different between allergen-stimulated $\mathrm{mDC}$ and control $\mathrm{mDC}$ (fig. 4c) suggesting an overall higher number of 


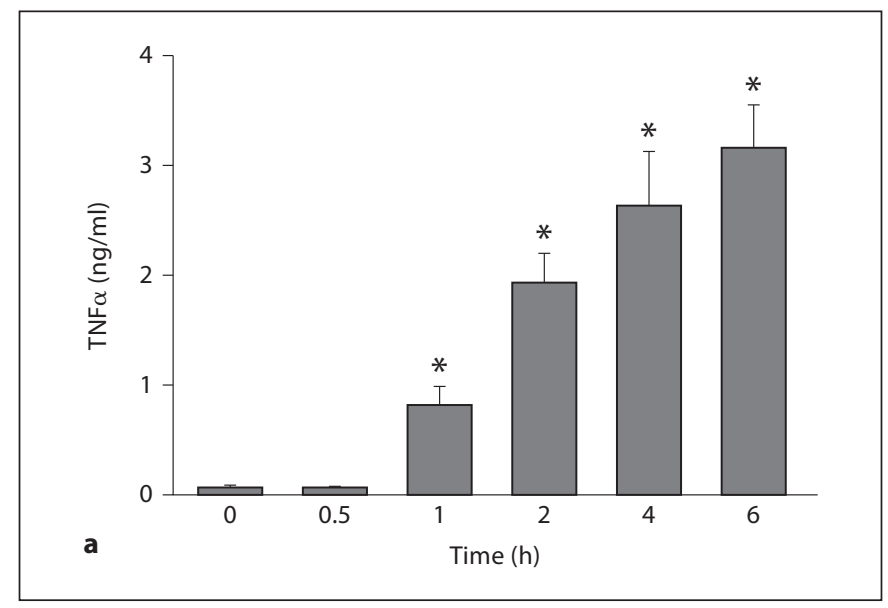

Fig. 3. BMDC secrete TNF $\alpha$ following GC frass exposure. BMDC from wild-type mice were cultured in the presence of GM-CSF for 6 days prior to treatment with GC frass $(1 \mu \mathrm{g} / \mathrm{ml})$. a $0.5-6 \mathrm{~h}$ later, cell supernatants were collected and analyzed for TNF $\alpha$ levels by ELISA. Means $\pm \operatorname{SEM}\left(\mathrm{n}=3-5\right.$ samples). ${ }^{*} \mathrm{p}<0.001$ (ANOVA). b BMDC were cultured in the presence or absence of GC frass

Table 2. Total number of TNF $\alpha$-positive cells in the lung $3 \mathrm{~h}$ after GC frass treatment

\begin{tabular}{lll}
\hline & \multicolumn{2}{l}{ TNF $\alpha+$ cells, $\times 10^{5}$ (means \pm SEM $)$} \\
\cline { 2 - 3 } & PBS & GC frass \\
\hline mDC & $2.8 \pm 0.2$ & $9.3 \pm 0.9^{*}$ \\
AM & $0.7 \pm 0.1$ & $1.0 \pm 0.2$ \\
Neutrophils & $1.1 \pm 0.1$ & $1.5 \pm 0.2$ \\
\hline
\end{tabular}

PBS or GC frass $(40 \mu \mathrm{g} / 40 \mu \mathrm{l})$ was administered intratracheally to $\mathrm{BALB} / \mathrm{c}$ mice and lungs were isolated $3 \mathrm{~h}$ later. Lungs were dissociated, immediately fixed, and permeabilized and stained for flow cytometry. mDC (CD11c+, CD11b+, Gr1-), alveolar macrophages (AM; CD11c+, CD11b-, Gr1-) and neutrophils (CD11c+, $\mathrm{CD} 11 \mathrm{~b}+, \mathrm{Gr} 1+)$ were analyzed for the number of cells expressing $\mathrm{TNF} \alpha . \mathrm{n}=8$ mice per group. Student's t test $\left({ }^{*} \mathrm{p}<0.001\right)$.

mDC synthesizing TNF $\alpha$. A similar profile was found when cells were incubated in the presence of monensin and brefeldin A overnight prior to fixation, permeabilization and staining for flow cytometry (data not shown). These data confirm that pulmonary $\mathrm{mDC}$ are capable of increased $\mathrm{TNF} \alpha$ production following allergen exposure.

\section{Respiratory Epithelial Cells Respond to TNF $\alpha$}

Next, we wanted to confirm the importance of TNF $\alpha$ in regulating respiratory epithelial cell production of

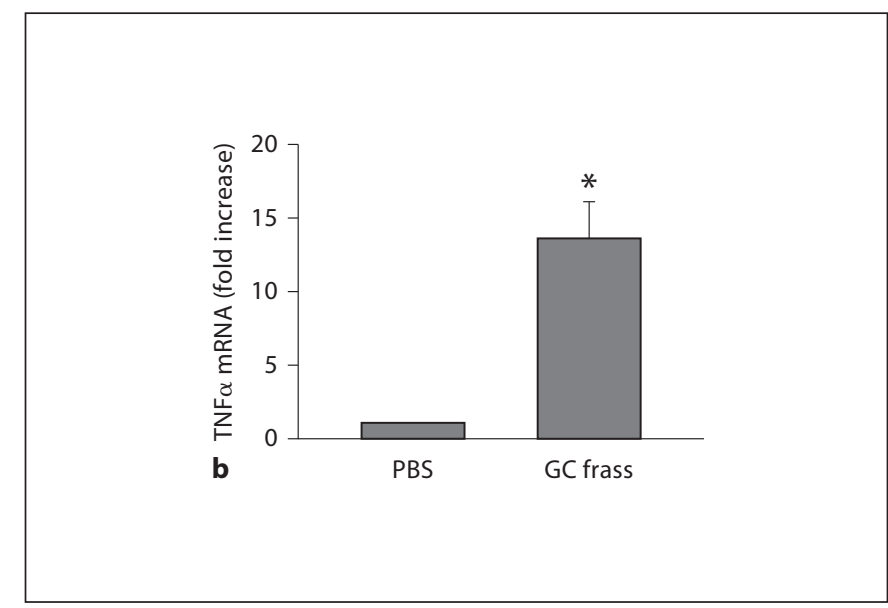

$(1 \mu \mathrm{g} / \mathrm{ml})$ for $4 \mathrm{~h}$. Cells were extracted in TRIzol, RNA was synthesized and converted to cDNA. Quantitative real-time PCR was performed. TNF $\alpha$ was normalized to $\beta$-actin and levels are expressed as fold increase over control (means \pm SEM for 3 separate experiments); ${ }^{*} \mathrm{p}=0.003$ (Student's t test).

CCL20 and GM-CSF. TNF $\alpha$ treatment significantly increased CCL20 and GM-CSF production in MLE-15 cells (fig. 5). Interestingly, GC frass was unable to significantly increase CCL20 or GM-CSF production. When TNF $\alpha$ and GC frass were added simultaneously, there was a synergistic increase in both CCL20 and GM-CSF production. These data confirm that epithelial cells respond to $\mathrm{TNF} \alpha$ and suggest the possibility that TNF $\alpha$ reprograms epithelial cell responses to make them more susceptible to allergen exposure.

\section{$B M D C$-Derived TNF $\alpha$ Regulates the Airways and}

Bronchoalveolar Epithelial Cells to Release CCL20

To confirm the role of DC-derived TNF $\alpha$ on modifying airway epithelial cell cytokine and chemokine production, we aimed to determine if CM from GC frasstreated BMDC was sufficient to regulate CCL20 production from epithelial cells. Consequently, we cultured BMDC and treated them with GC frass for $6 \mathrm{~h}$. CM was removed, clarified and added to cultured primary MTEC; $18 \mathrm{~h}$ after the addition of BMDC-CM to MTEC; the supernatant was removed and analyzed for CCL20 production. It is important to note that BMDC do not secrete CCL20 or GM-CSF following exposure to GC frass (data not shown). We found that CM from GC frass-treated BMDC significantly increased CCL20 production from MTEC (fig. 6a) and MLE-15 cells (fig. 6b). To confirm that $\mathrm{TNF} \alpha$ release from BMDC was responsible for the in- 


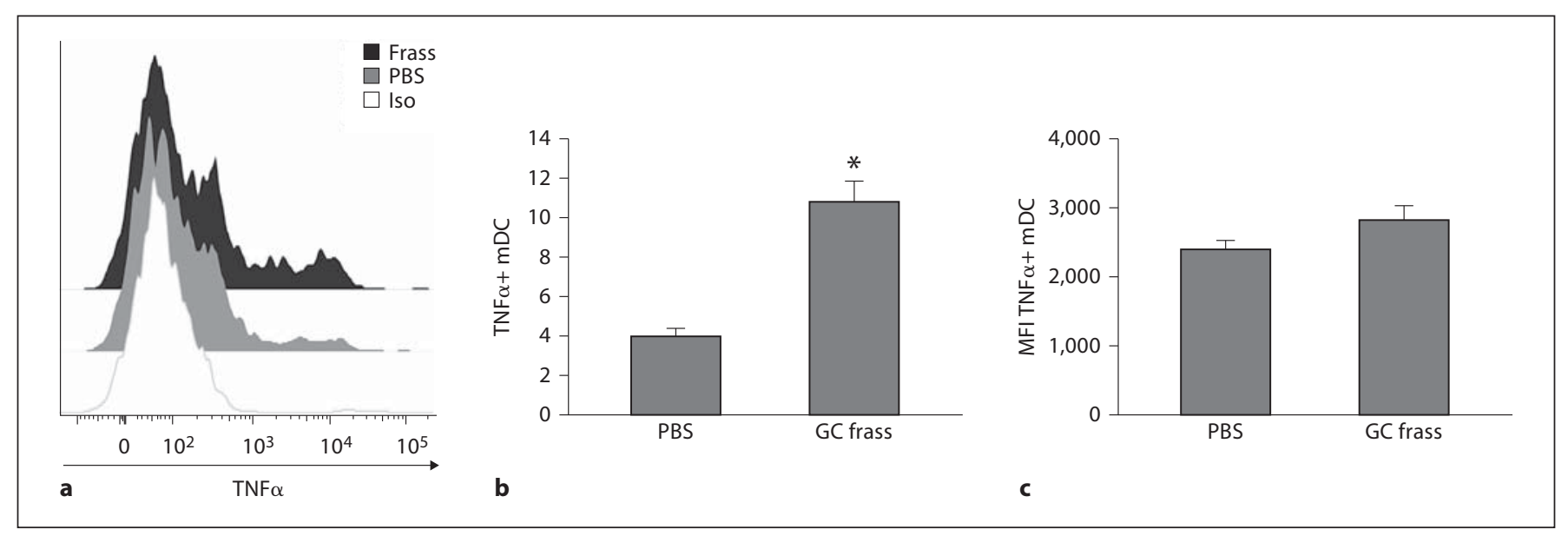

Fig. 4. Pulmonary DC secrete TNF $\alpha$. Naïve mice were administered a single instillation of PBS or GC frass $(40 \mu \mathrm{g} / 40 \mu \mathrm{l}) ; 3 \mathrm{~h}$ later, the lungs were removed and cells were isolated and immediately fixed and permeabilized prior to staining for flow-cytometric analysis of TNF $\alpha$ expression. Cells were gated on CD11c+,
$\mathrm{CD} 1 \mathrm{~b}+, \mathrm{Grl}-$ for mDC and were further analyzed by intracellular staining of TNF $\alpha$. a Representative histogram. b Percentage of TNF $\alpha+$ mDC (* $\mathrm{p}<0.001$, Student's t test). c Mean fluorescence intensity (MFI) of TNF $\alpha+$ mDC. Means \pm SEM, $n=8$ mice/group.
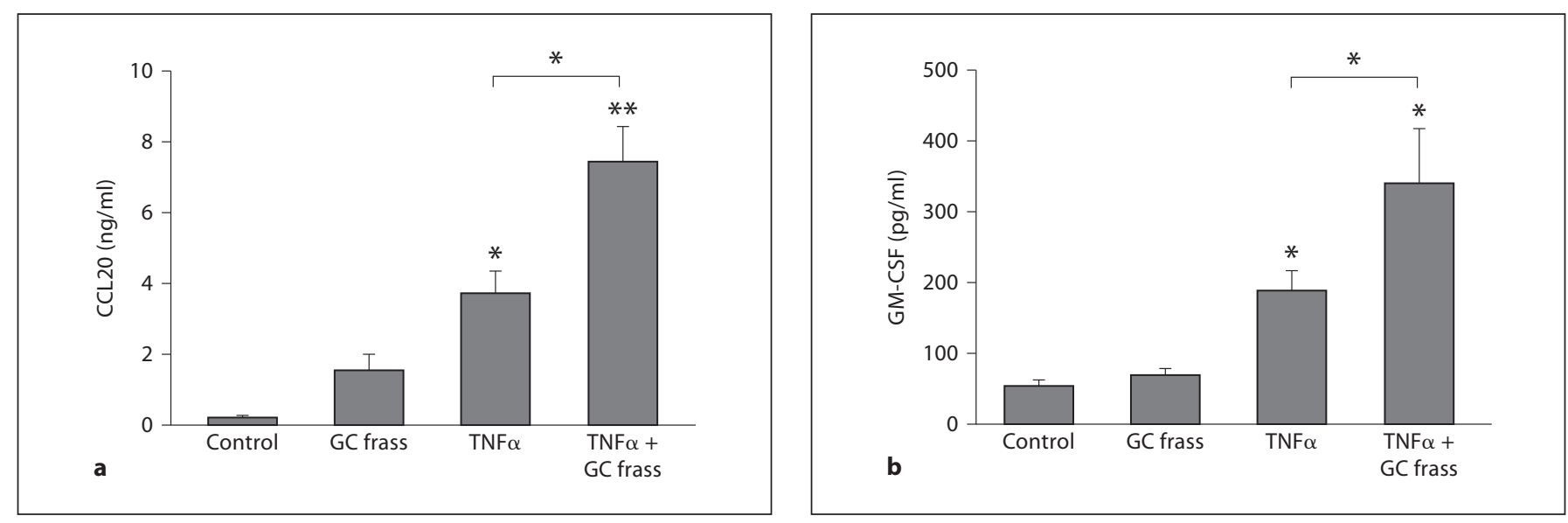

Fig. 5. MLE- 15 response to TNF $\alpha$ and GC frass treatment. MLE-15 cells were cultured in the presence of GC frass ( $1 \mu \mathrm{g} / \mathrm{ml})$ or TNF $\alpha$ $(10 \mathrm{ng} / \mathrm{ml})$ for $18 \mathrm{~h}$, at which time cell supernatants were collected and analyzed for CCL20 and GM-CSF expression. Means \pm SEM for 4 separate experiments. a CCL20 $\left({ }^{*} \mathrm{p}<0.001,{ }^{* *} \mathrm{p}<0.05\right)$. b GM-CSF $\left({ }^{*} \mathrm{p}<0.05\right)$.

crease in CCL20 production from respiratory epithelial cells, we treated selected MLE-15 cells with a TNFR-neutralizing antibody. Blocking TNFR1 totally abolished CCL20 production (fig. 6c), suggesting a role for BMDC TNF $\alpha$ in activating MLE-15 cells to synthesize CCL20. Lastly, we wanted to confirm that residual GC frass that may be in the BMDC-CM is not responsible for the increase in CCL20 production. Therefore, BMDC were treated with GC frass for $6 \mathrm{~h}$, cells were washed to remove any residual GC frass and BMDC were co-cultured with MLE-15 cells. Importantly, we found that GC frass-stimulated BMDC were sufficient to regulate MLE-15-induced production of CCL20 (fig. 6d). We confirmed that GC frass-conditioned BMDC media also increased GM-CSF production in primary MTEC (fig. 7a) and that blocking TNFR1 abolished GM-CSF production in MLE-15 cells (fig. 7b). Together these data suggest the likelihood that the DC can immediately respond to allergen exposure by 
Fig. 6. DC-derived $\mathrm{TNF} \alpha$ regulates airway epithelial cell CCL20 production (a). BMDC were cultured in the presence of PBS or GC frass $(1 \mu \mathrm{g} / \mathrm{ml})$ for $6 \mathrm{~h}$, at which time CM was harvested and clarified. MTEC were grown to confluence, washed in PBS and treated with CM from PBS- or GC frass-treated BMDC for $18 \mathrm{~h}$. Media were harvested, clarified and analyzed for CCL20 production by ELISA. Means \pm SEM for 6 separate experiments $\left({ }^{*} \mathrm{p}<\right.$ 0.001). b BMDC CM was added to MLE-15 cells. Means \pm SEM for 5 separate experiments ( $\left.{ }^{*} p=0.008\right)$. c Upon addition of CM to MLE-15 cells, either an isotype control Ab (IgG) or an antibody against TNFR1 was added. Means \pm SEM for 4 separate experiments $\left({ }^{*} \mathrm{p}<0.001\right)$. d BMDC were cultured in the presence of PBS or GC frass $(1 \mu \mathrm{g} / \mathrm{ml})$ for $6 \mathrm{~h}$, at which time the cells were washed with PBS, and $1 \times 10^{6}$ cells were added to the MLE-15 cells; $18 \mathrm{~h}$ later, media were isolated and analyzed for CCL20 production by ELISA. Means \pm SEM for 5 separate experiments $\left({ }^{*} \mathrm{p}<\right.$ 0.001).

Fig. 7. DC-derived $\mathrm{TNF} \alpha$ regulates airway epithelial cell GM-CSF production (a). BMDC were cultured in the presence of PBS or GC frass $(1 \mu \mathrm{g} / \mathrm{ml})$ for $6 \mathrm{~h}$, at which time CM was harvested and clarified. MTEC were grown to confluence, washed in PBS and treated with CM from PBS- or GC frass-treated BMDC for $18 \mathrm{~h}$. Media were harvested, clarified and analyzed for CCL20 production by ELISA. Means \pm SEM for 3 separate experiments $\left({ }^{*} \mathrm{p}<0.05\right)$. b Using MLE- 15 cells, upon addition of CM from PBS- or GC frass-treated BMDC, either an isotype control $\mathrm{Ab}(\mathrm{IgG})$ or an antibody against TNFR1 was added. Means \pm SEM for 4 separate experiments $\left({ }^{*} \mathrm{p}<0.05\right)$.
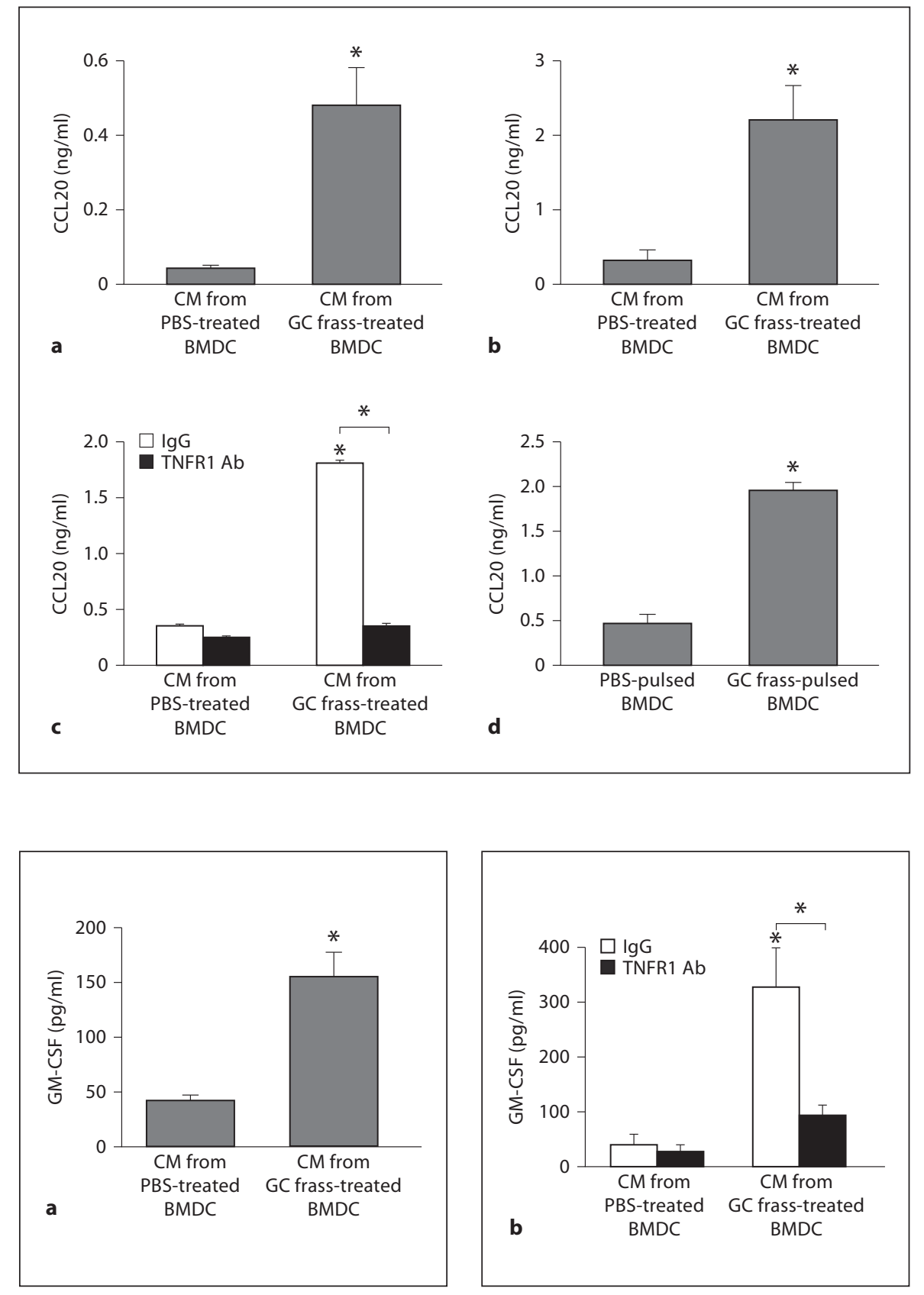

releasing significant quantities of $\mathrm{TNF} \alpha$ which then act on the airway epithelial cells via TNFR1 to mediate their production of CCL20 and GM-CSF in vitro.

\section{Blocking TNFR1 in the Lung Resulted in Decreased Airway CCL20 and GM-CSF Production}

To address the importance of TNF $\alpha$ release on the upregulation of CCL20 and GM-CSF in vivo, we administered a TNFR1 antibody intratracheally $24 \mathrm{~h}$ prior to the instillation of PBS or GC frass. Three hours after allergen challenge; BAL fluid was isolated and analyzed for CCL20, GM-CSF and TNF $\alpha$. We found a significant decrease in CCL20 and GM-CSF production in the lung following inhibition of TNFR1 compared with an isotype control antibody (fig. 8). TNF $\alpha$ levels were largely unaffected (data not shown). These data highlight the importance of early TNF $\alpha$ release on cytokine production via TNFR1 in vivo. 


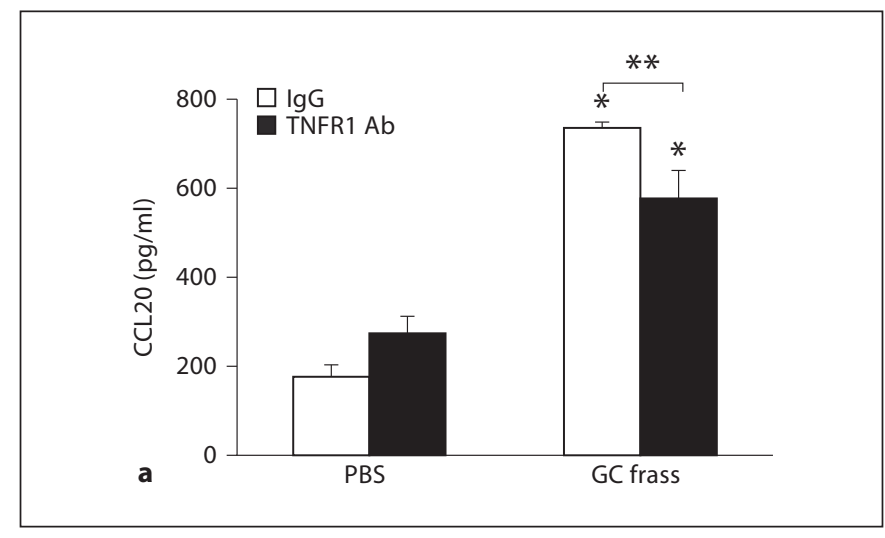

Fig. 8. Blocking TNFR1 in vivo alters CCL20 and GM-CSF release. BALB/c mice were administered isotype control or TNFR1 antibody $(25 \mu \mathrm{g} / 50 \mu \mathrm{l})$ via intratracheal instillation; $20 \mathrm{~h}$ later, mice were given a single exposure to PBS or GC frass $(40 \mu \mathrm{g} / 40$

\section{Discussion}

In this report, we describe a paradigm in which DC play a crucial role in the initiation of innate immune responses via early release of TNF $\alpha$, which modifies cytokine expression of airway epithelial cells and the ability of these cells to respond to allergen. A number of findings suggest that DC-derived TNF $\alpha$ is the crucial component in reprogramming the early responses of lung epithelial cells including (1) the early and substantial release of TNF $\alpha$ by BMDC and pulmonary DC but not airway or bronchoalveolar epithelial cells, neutrophils or alveolar macrophages; (2) CM from GC frass-pulsed DC modulate chemokine production from lung epithelial cells, and (3) blocking TNFR1 resulted in decreased CCL20 and GM-CSF production from lung epithelial cells in vitro and in vivo. The fact that TNF $\alpha$ is a potent stimulator of airway epithelial cells and many of the cytokines and chemokines produced by these epithelial cells are activated by $\mathrm{TNF} \alpha$ lends credibility to the idea that TNF $\alpha$ initiates the innate immune response to allergen exposure. Our findings indicate that the early source of allergen-derived $\mathrm{TNF} \alpha$ is from the early activation of airway mDC.

The importance of airway DC in the early response to allergen exposure is validated by the finding that airway $\mathrm{mDC}$, but not alveolar macrophages or neutrophils, increased intracellular $\mathrm{TNF} \alpha$ production $3 \mathrm{~h}$ after allergen challenge. By flow cytometry, we failed to detect significant increases in intracellular TNF $\alpha$ in alveolar macrophages and neutrophils, results correlating with our in vitro and in vivo studies and suggesting that $\mathrm{mDC}$ are the

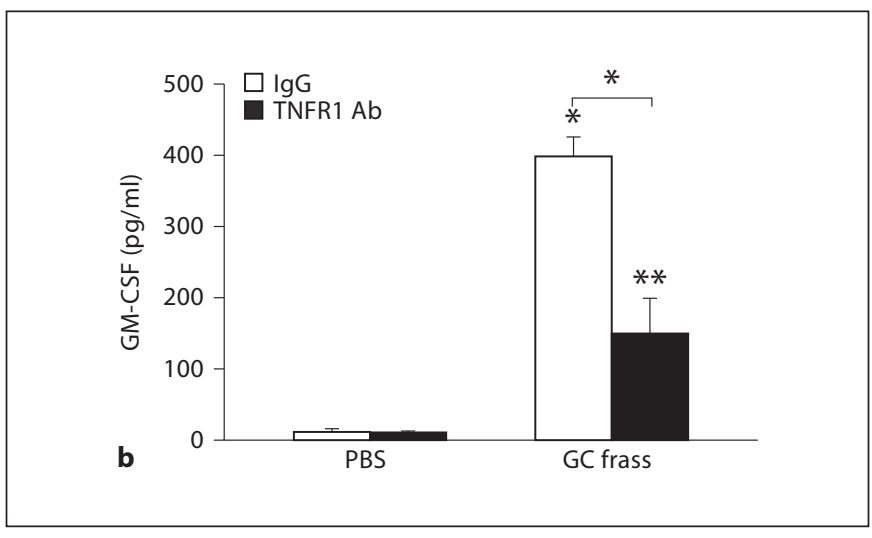

$\mu \mathrm{l}$ ), and $3 \mathrm{~h}$ later, BAL fluid was isolated, clarified and ELISA performed on the BAL fluid. Means \pm SEM; $n=4$ mice/group); ${ }^{*} \mathrm{p}<0.001 ;{ }^{* *} \mathrm{p}<0.05$ (ANOVA). a CCL20 levels. b GM-CSF levels.

primary source of early TNF $\alpha$ release. Since only a small proportion of whole lung $\mathrm{mDC}$ are likely to encounter allergen, it is anticipated that only a proportion of all $\mathrm{CD} 1 \mathrm{c}+\mathrm{CD} 1 \mathrm{~b}+\mathrm{Gr1}-$ cells in the whole lung will be $\mathrm{TNF} \alpha+$. However, we predict that the TNF $\alpha$-producing DC are localized in the intraepithelial layer and that their production of $\mathrm{TNF} \alpha$ is likely to be sufficient to regulate airway epithelial cell responses in the lung. Future studies will define the actual location of TNF $\alpha$-producing $\mathrm{mDC}$ in the lung.

We have previously shown that GC extract alone was insufficient to induce IL-8 cytokine production using the human bronchial epithelial cell line 16HBE14o- and primary normal human bronchial epithelial cells, but synergistically increased TNF $\alpha$-induced IL- 8 expression [26-28]. These data would support a crucial role for the presence of TNF $\alpha$ in the airways when allergen is encountered. Other groups have shown that addition of GC extract alone was sufficient to induce IL- 8 production in A549 (adenocarcinomic human alveolar epithelial cells) and H292 (human epithelial carcinoma) cell lines [29, 30]. The differences between these studies and ours include the use of the carcinoma cells, which may have different responses to stimuli than normal cells, and the very high doses of cockroach extract $(10-100 \mu \mathrm{g} / \mathrm{ml})$ applied. The current study supports our earlier work in the fact that GC frass induced minimal CCL20 and GM-CSF production from MLE-15 cells; however, the combined treatment of TNF $\alpha$ and GC frass led to optimal chemokine production. Together these data suggest that the initial release of DC-derived TNF $\alpha$ alters the airway micro- 
environment to more marked response of airway and bronchoalveolar epithelial cells to allergen exposure.

Recently, TNF $\alpha$ was shown to enhance TGF- $\beta_{1}$-driven epithelial-to-mesenchymal transition [31], suggesting that it could be a central component leading to the reprogramming of airway epithelial cell responses. In another study, DC cultured in the presence of lipopolysaccharides were able to secrete exovesicles containing TNF $\alpha$ into cell culture media. The TNF $\alpha$-containing exovesicles were then internalized by epithelial cells through receptor-mediated endocytosis and resulted in IL-8, MCP-1 and G-CSF release from epithelial cells [32]. This study was of particular interest as they also concluded that DC are important carriers of TNF $\alpha$ and are involved in the activation of airway epithelial cells. While we did not investigate the mechanism by which TNF $\alpha$ was secreted, we did note increased transcription of $\mathrm{TNF} \alpha$, suggesting upregulation of a signaling pathway leading to TNF $\alpha$ production. While beyond the scope of this study, it is likely that activation of pattern recognition receptors may play a role. Future studies will explore the mechanisms of pattern recognition receptor binding, including the role of endotoxin, lipoproteins and proteases, in activating mucosal DC to secrete TNF $\alpha$. Since GC frass is complex and contains agonists for Toll-like receptors (TLR2 and TLR4) as well as serine proteases that activate PAR-2 [15, 21, 22], we anticipate the activation of $\mathrm{mDC}$ to be complex as well.

It is interesting to consider a role for the intraepithelial DC in modulating immune responses. The nature of DC is to become adapted to the highly specialized environment in which they are located [33]. Based on the findings by Jahnsen et al. [19] who eloquently showed that airway mucosal DC represent a 'maturational continuum' as they progress through the subepithelial layers, it is possible that the CCL20 and GM-CSF released by airway epithelial cells following antigen exposure may aid in the maturation process of the underlying DC. In addition, it is known that TNF $\alpha$ aids in the maturation process of DC by increasing co-stimulatory molecule expression, cytokine production and T-cell activation [34]. In addition, a recent study showed that DC-derived TNF $\alpha$ differed between mouse strains and that $\mathrm{TNF} \alpha$ levels played a role in IL-17A production in the lung [35]. We have recently shown an increase in IL-17A following a single exposure to GC frass, as well as following adoptive transfer of GC frass-pulsed mDC [36]. While we did not address this in the current study, based on the work by Fei et al. [35] it is possible that the DC-derived $\mathrm{TNF} \alpha$ could be mediating the increase in IL-17A. Together, these data could suggest that the early activation of DC to produce TNF $\alpha$ could both modify airway epithelial cell responses to allergen exposure as well as induce DC maturation for optimal allergen uptake and processing.

We acknowledge the artificial nature of culturing the mDC, alveolar macrophages and the primary tracheal epithelial cells and studying the kinetics following various treatments; however, we anticipate that the interactions between these cells play an important role in the magnitude of responses to inhaled antigen. While future studies will need to be performed in a more tightly controlled system, we believe our findings strongly suggest that $\mathrm{mDC}$ could be the initiators of very early innate immune responses and that this early release of TNF $\alpha$ by DC could begin the process towards the generation of allergic airway responses. Therapeutically, the options of targeting the DC may be less challenging than targeting the airway epithelium, and a more comprehensive investigation into the activation of DC may provide potential new therapeutic options for the treatment of allergic airway disorders in the future.

\section{References}

-1 Puddicombe SM, Polosa R, Richter A, Krishna MT, Howarth PH, Holgate ST, Davies DE: Involvement of the epidermal growth factor receptor in epithelial repair in asthma. FASEB J 2000;14:1362-1374.

$>2$ Kicic A, Sutanto EN, Stevens PT, Knight DA, Stick SM: Intrinsic biochemical and functional differences in bronchial epithelial cells of children with asthma. Am J Respir Crit Care Med 2006;74:1110-1118.

$>3$ Stevens PT, Kicic A, Sutanto EN, Knight DA, Stick SM: Dysregulated repair in asthmatic paediatric airway epithelial cells: the role of plasminogen activator inhibitor-1. Clin Exp Allergy 2008;38:1901-1910.
4 Kicic A, Hallstrand TS, Sutanto EN, Stevens PT, Kobor MS, Taplin C, Paré PD, Beyer RP, Stick SM, Knight DA: Decreased fibronectin production significantly contributes to dysregulated repair of asthmatic epithelium. Am J Respir Crit Care Med 2010;181:889898.

5 Bayram H, Devalia JL, Sapsford RJ, Othoshi T, Miyabara Y, Sagai M, Davies RJ: The effect of diesel exhaust particles on cell function and release of inflammatory mediators from human bronchial epithelial cells. Am J Respir Cell Mol Biol 1998;18:441-448.
-6 Calderón MA, Devalia JL, Prior AJ, Sapsford RJ, Davies RJ: A comparison of cytokine release from epithelial cells cultured from nasal biopsy specimens of atopic patients with and without rhinitis and nonatopic subjects without rhinitis. J Allergy Clin Immunol 1997;99:65-76.

7 Lordan JL, Bucchieri F, Richter A, Konstantinidis A, Holloway JW, Thornber M, Puddicombe SM, Buchanan D, Wilson SJ, Djukanovic R, et al: Cooperative effects of Th2 cytokines and allergen on normal and asthmatic bronchial epithelial cells. J Immunol 2002;169:407-414. 
8 Nakae S, Lunderius C, Ho LH, Schäfer B, Tsai M, Galli SJ: TNF can contribute to multiple features of ovalbumin-induced allergic inflammation of the airways in mice. J Allergy Clin Immunol 2007;119:680-686.

-9 Ying S, Robinson DS, Varney V, Meng Q, Tsicopoulos A, Moqbel R, Durham SR, Kay AB, Hamid Q: TNF alpha mRNA expression in allergic inflammation. Clin Exp Allergy 1991;21:745-750.

10 Bradding P, Roberts JA, Britten KM, Montefort S, Djukanovic R, Mueller R, Heusser $\mathrm{CH}$, Howarth PH, Holgate ST: Interleukin-4, -5 , and -6 and tumor necrosis factor-alpha in normal and asthmatic airways: evidence for the human mast cell as a source of these cytokines. Am J Respir Cell Mol Biol 1994;10: 471-480.

-11 Babu SK, Puddicombe SM, Arshad HH, Wilson SJ, Ward J, Gozzard N, Higgs G, Holgate ST, Davies DE: Tumor necrosis factor alpha $(\mathrm{TNF}-\alpha)$ autoregulates its expression and induces adhesion molecule expression in asthma. Clin Immunol 2011;140:18-25.

$\checkmark 12$ Kao CY, Huang F, Chen Y, Thai P, Wachi S, Kim C, Tam L, Wu R: Up-regulation of CC chemokine ligand 20 expression in human airway epithelium by IL-17 through a JAKindependent but MEK/NF- $\kappa \mathrm{B}$-dependent signaling pathway. J Immunol 2005;175: 6676-6685.

13 Dieu MC, Vanbervliet B, Vicari A, Bridon JM, Oldham E, Aït-Yahia S, Brière F, Zlotnik A, Lebecque S, Caux C: Selective recruitment of immature and mature dendritic cells by distinct chemokines expressed in different anatomic sites. J Exp Med 1998;188:373-386.

-14 Hashimoto S, Matsumoto K, Gon Y, Maruoka S, Kujime K, Hayashi S, Takeshita I, Horie T: p38 MAP kinase regulates TNF alpha-, IL-1 alpha- and PAF-induced RANTES and GM-CSF production by human bronchial epithelial cells. Clin Exp Allergy 2000;30:48-55.

15 Page K, Lierl KM, Hughes VS, Zhou P, Ledford JR, Wills-Karp M: TLR2-mediated activation of neutrophils in response to German cockroach frass. J Immunol 2008;180:63176324.

16 Ohkawara Y, Yamauchi K, Tanno Y, Tamura G, Ohtani H, Nagura H, Ohkuda K, Takishima T: Human lung mast cells and pulmonary macrophages produce tumor necrosis factor-alpha in sensitized lung tissue after IgE receptor triggering. Am J Respir Cell Mol Biol 1992;7:385-392.
17 Hortobágyi L, Kierstein S, Krytska K, Zhu X, Das AM, Poulain F, Haczku A: Surfactant protein D inhibits TNF-alpha production by macrophages and dendritic cells in mice. J Allergy Clin Immunol 2008;122:521-528.

18 Rescigno M, Urbano M, Valzasina B, Francolini M, Rotta G, Bonasio R, Granucci F, Kraehenbuhl JP, Ricciardi-Castagnoli P: Dendritic cells express tight junction proteins and penetrate gut epithelial monolayers to sample bacteria. Nat Immunol 2001;2: 361-367.

19 Jahnsen FL, Strickland DH, Thomas JA, Tobagus IT, Napoli S, Zosky GR, Turner DJ, Sly PD, Stumbles PA, Holt PG: Accelerated antigen sampling and transport by airway mucosal dendritic cells following inhalation of a bacterial stimulus. J Immunol 2006;177: 5861-5867.

20 Walters DM, Breysse PN, Wills-Karp M: Ambient urban Baltimore particulate-induced airway hyperresponsiveness and inflammation in mice. Am J Respir Crit Care Med 2001;164:1438-1443.

21 Page K, Ledford JR, Zhou P, Wills-Karp M: Mucosal sensitization to German cockroach involves protease-activated receptor-2. Respir Res 2010;11:62.

22 Page K, Lierl K, Herman N, Wills-Karp M: Differences in susceptibility to German cockroach frass and its associated proteases in induced allergic inflammation in mice. Respir Res 2007;8:91.

23 Czuprynski CJ, Brown JF, Maroushek N, Wagner RD, Steinberg H: Administration of anti-granulocyte mAb RB6-8C5 impairs the resistance of mice to Listeria monocytogenes infection. J Immunol 1994;152:1836-1846.

24 Pfaffl MW: A new mathematical model for relative quantification in real-time RT-PCR. Nucleic Acid Res 2001;29:45.

25 Wikenheiser KA, Vorbroker DK, Rice WR, Clark JC, Bachurski CJ, Oie HK, Whitsett JA: Production of immortalized distal respiratory epithelial cell lines from surfactant protein $\mathrm{C} /$ simian virus 40 large tumor antigen transgenic mice. Proc Natl Acad Sci USA 1993;90:11029-11033.

26 Bhat RK, Page K, Tan A, Hershenson MB: German cockroach extract increases bronchial epithelial cell interleukin-8 expression. Clin Exp Allergy 2003;33:35-42.
Page K, Hughes VS, Odoms KK, Dunsmore KE, Hershenson MB: German cockroach proteases regulate IL- 8 expression via NFIL6 in human bronchial epithelial cells. Am J Respir Cell Mol Biol 2005;32:225-231.

28 Page K, Strunk VS, Hershenson MB: Cockroach proteases increase IL-8 expression in human bronchial epithelial cells via activation of protease-activated receptor (PAR)-2 and ERK. J Allergy Clin Immunol 2003;112: $1112-1118$

29 Kuderer NM, San-Juan-Vergara HG, Kong X, Esch R, Lockey RF, Mohapatra SS: Mite and cockroach proteases activate p44/p42 MAP kinases in human lung epithelial cells. Clin Mol Allergy 2003;1:1.

30 Lee KE, Kim JW, Jeong KY, Kim KE, Yong TS, Sohn MH: Regulation of German cockroach extract-induced IL-8 expression in human airway epithelial cells. Clin Exp Allergy 2007:37:1364-1373.

31 Camara J, Jarai G: Epithelial-mesenchymal transition in primary human bronchial epithelial cells is Smad-dependent and enhanced by fibronectin and TNF- $\alpha$. Fibrogenesis Tissue Repair 2010;3:2

- 32 Obregon C, Rothen-Rutishauser B, Gerber P, Gehr P, Nicod LP: Active uptake of dendritic cell-derived exovesicles by epithelial cells induces the release of inflammatory mediators through a TNF-alpha-mediated pathway. Am J Pathol 2009;175:696-705.

-33 Soloff AC, Barratt-Boyes SM: Enemy at the gates: dendritic cells and immunity to mucosal pathogens. Cell Res 2010;20:872-885.

-34 Brunner C, Seiderer J, Schlamp A, Bidlingmaier M, Eigler A, Haimerl W, Lehr HA, Krieg AM, Hartmann G, Endres S: Enhanced dendritic cell maturation by TNFalpha or cytidine-phosphate-guanosine DNA drives $\mathrm{T}$ cell activation in vitro and therapeutic anti-tumor immune responses in vivo. J Immunol 2000;165:6278-6286.

35 Fei M, Bhatia S, Oriss TB, Yarlagadda M, Khare A, Akira S, Saijo S, Iwakura Y, Fallert Junecko BA, Reinhart TA, et al: TNF-alpha from inflammatory dendritic cells (DCs) regulates lung IL-17A/IL-5 levels and neutrophilia versus eosinophilia during persistent fungal infection. Proc Natl Acad Sci USA 2011;108:5360-5365.

- 36 Page K, Zhou P, Ledford JR, Day SB, Lutfi R, Dienger K, Lewkowich IP: Early immunological response to German cockroach frass exposure induces a Th2/Th17 environment. J Innate Immun 2011;3:167-179. 